\title{
The Effectiveness of the Implementation of Online Lectures on Student Satisfaction in Higher Education Institutions (Case Study of the President University)
}

\author{
Yeni Fajrin ${ }^{1}$, Adhi Setyo Santoso ${ }^{2 *}$ \\ ${ }^{12}$ President University, Bekasi 17550, Indonesia
}

\begin{abstract}
A B S T R A C T
This study aims to identify and obtain information about the effectiveness of the implementation of online lectures during the COVID-19 pandemic at Higher Education Institutions, especially at President University. Data was collected by looking at the results of student satisfaction assessments of lecturers during the teaching and learning process, namely in the PUIS (President University Information System) system in the "Lecturing Evaluation" menu. The research uses quantitative methods and data analysis using SPSS software with Two Way Anova analysis. After the data were analyzed, the researcher approached using online interviews with 12 lecturers, to dig deeper information about online and offline lectures. The results of this study are that there is a significant difference in satisfaction between offline and online lectures, namely, when offline class students can get knowledge directly without any technical constraints and face-to-face teaching and learning process there are values that can be taken such as the process of social, cultural, ethical maturity and morals that can only be found in the area of education. In contrast to online lectures, apart from technical constraints such as the unsupported internet, online classes make students lose motivation to learn because of the absence of chemistry. There are different characteristics in each faculty, this is a challenge for lecturers to explore their abilities and provide new knowledge, and of course, it can be well accepted by students. Online classes will run more effectively if lecturers and students can collaborate and communicate well and make the best use of technology.
\end{abstract}

ART ICLE INFO

Article History:

Received : 01-12-2020

Revised : 30-05-2021

Accepted : 23-06-2021

Published : 30-06-2021

Keywords:

COVID-19

Online Lectures

Student Satisfaction

JEL: M10, M31, M20

*Corresponding Author E-mail:

adhi.setyo@president.ac.id 


\section{INTRODUCTION}

Today the world community is being worried about the Corona Virus Disease (COVID-19) outbreak which has become a pandemic. The government has made several policies to stop the spread of this epidemic, such as conducting lockdowns in areas that are already included in the red zone for the spread of the virus, then physical quarantine to prevent the spread of the virus through physical contact. Likewise with Indonesia, many ways have been used by the government to prevent its spread. One of them is through a circular letter from the Ministry of Education and Culture (Kemendikbud) of the Directorate of Higher Education No. 1 of 2020 concerning the prevention of the spread of Corona Virus Disease (Covid-19) in universities. Through this circular, the Ministry of Education and Culture provides instructions for universities to conduct distance learning and advises students to study from their respective homes. Many universities respond readily to these instructions, one of which is President University. President University instructs students and faculty to undertake lectures online. There are many pros and cons when applying remote lectures, both from the point of view of students and lecturers. Distance learning motivation for students is considered as an easing of the intention to face to face with the teacher because this activity can be done while relaxing in their respective residences. But on the other hand, lecture and practical activities, exams, thesis guidance, and other activities are assumed to be new problems for teachers and students.

Many factors become an obstacle in implementing online lectures at higher education institutions, including:

1. Unsupported internet, unclear understanding of the material due to slow internet networks, irregular sleep schedules, and disruption of home and other activities.

2. For students majoring in social, online lectures may not be a problem, but for students majoring in science and engineering, this is a problem because practical lectures or practicum that must be done in a laboratory will be difficult to do because there are no tools or facilities that can be used during online classes.

3. Every course, almost all lecturers give assignments, so that the assignments become to pile up because it is considered that students have to do the task as a substitute for the study time that should be spent if there is an explanation of the material, in other words, it is not online lectures that occur but online assignments.

4. It is difficult to apply courses that should go directly to the field to provide experience for students to play a role and carry out these procedures or materials.

The purpose of this research is expected to help provide an overview of the performance of online lectures and be able to see how online lectures are carried out so that they can help see the development of online lectures at the President's University. The results of this study will be used to measure student satisfaction when online lectures are applied (after Covid-19) compared to offline lectures (before Covid-19), as well as to measure student satisfaction between faculties in carrying out lectures both online and offline classes.

\section{LITERATURE REVIEW}

\section{Distance Learning in Higher Education Institutions}

Distance Learning in Higher Education Institutions greatly influences the teaching and learning process of students and lecturers themselves, where they have to run online lectures, according to (Firman, F., \& Rahayu, S. 2020) the results of research show that, in carrying out online learning, students must be prepared with the basic facilities needed. Then, running the teaching and learning process online makes you more active in learning because of the flexible time so that it provides motivation and independence in learning. Social distancing is a way to minimize the potential for the spread of Covid-19 in the campus environment, namely by distance learning. 


\section{Challenges of Online Learning in Higher Education Institutions}

Research data from Firman, F., \& Rahayu, S. (2020) shows that online learning has its challenges, namely, the availability of internet services, most students access the internet using cellular services, while a small proportion uses WiFi services. For students who use cellular services, sometimes it is difficult to get a signal, this makes students late in getting lecture information and submitting coursework. Then the cost constraints, students stated that to take part in online learning, they had to pay more to buy internet data quota. The location of separate lecturers and students when carrying out learning makes lecturers unable to directly monitor student activities during the lecture process. There is no guarantee that students pay attention to the explanation given by the lecturer. Szpunar, Moulton, \& Schacter, (2013) stated that students fantasize more often in online lectures compared to face-to-face lectures. For this reason, Khan (2012) suggests that online lectures should be carried out in a short time because students have difficulty maintaining concentration if online lectures are held for more than one hour. Students have difficulty understanding the course material provided online. Too much lecture material and reading material cannot be comprehensively understood by students. Students assume that just reading the material and doing assignments is not enough, what they need is a direct verbal explanation from the lecturer concerned. Communication with lecturers through the instant message application or in the discussion column provided by the virtual classroom application is unable to provide a comprehensive explanation of the material being discussed. Then, Garrison \& Cleveland-Innes (2005) researched by engineering the involvement of lecturers in online lectures. In a class where there is very little involvement of the lecturer, it does not indicate deep and meaningful learning. Interaction with lecturers is very important in online learning because it can reduce psychological distance which in turn will lead to better learning (Swan, 2002).

\section{Positive and Negative Impacts of Online} Lectures for Higher Education Institutions

Positive and negative impacts of online lectures for Lecturers and Students According to Rokhani's research, Cicilia Tri Suci, 2020, namely, the positive impact, both lecturers and students can save energy, time, and money because they no longer need to go to campus. Students and lecturers can master technology to support online learning. Lecturers and Students will also have a little free time to do other work at home. Then for the negative impact for Lecturers and Students, namely, Online Class makes Lecturers and Students bored with a monotonous learning atmosphere. Then, reducing the interaction between Lecturers, Educators, and Students. Online Class is also possible to reduce the quality of the teaching and learning process because there is no direct interaction during the teaching and learning process between Lecturers and Students. Then, Online Class makes lecturers and students unable to focus sometimes because of the interaction with their family members when teaching and learning take place.

\section{RESEARCH METHOD}

This research used quantitative methods and data analysis using SPSS version 21 software with Two Way Anova analysis. Data was collected by looking at the results of student satisfaction assessments of lecturers during the teaching and learning process, namely in the PUIS (President University Information System) system in the "Lecturing Evaluation" menu. The data taken is lectures before covid-19 (offline class), namely the 2018/2019 academic year in semester II (two) and semester III (three), while data after covid-19 (online class) is the 2019/2020 school year in semester II (two) and semester III (three). The subjects assessed were the differences in the results of lectures carried out after COVID-19 (online) and before COVID-19 (offline) on student satisfaction. The assessment was conducted in 4 (four) faculties, namely the Faculty of Computing (FOC), Faculty of Business (FOB), Faculty of Engineering (FOE), and Faculty of Humaniora (FOH) a total of 318 students, and the research 
approach used the interview method which was carried out continuously. online using google meets with 12 (twelve) lecturers from the 4 (four) Faculties.

Many factors become an obstacle in carrying out lectures online, in addition to technical constraints such as the internet that does not support, the mental readiness of students is also a big obstacle, because it could be that from all the subjects studied, all lecturers give assignments so that the task becomes solid and many. Then for students majoring in social, online classes may not be a scary problem because they only move presentations from offline to online, but for science and engineering students this becomes a difficult thing because several courses must be done in practice, be it practicum in the laboratory or plunging directly into the field is simply impossible. In addition, in terms of understanding the material presented, maybe some students can immediately understand what the lecturer explains, but some students find it difficult to understand the material, what else must be conveyed online, things like that must be paid more attention to. and of course, it is a big challenge for lecturers to be more creative in delivering material so that online lectures can be accepted and understood well by students. Based on this explanation, the research questions in this study are:

1. Are there differences in lecture satisfaction before Covid-19 (offline class) and after Covid19 (online class) between faculties?
2. Are there differences in characteristics between Faculties before Covid-19 (offline class) and after Covid-19 (online class)?

3. How can I make online classes run more effectively?

\section{RESULT AND DISCUSSION}

\section{Two Way ANOVA Analysis Test}

Hypothesis testing in this study uses a two-way analysis of variance (ANOVA). Two-way ANOVA is used when data analysis wants to know whether or not there is a difference between the two independent variables, while each independent variable is divided into several groups.

In this study, there are two variables used as the basis for reviewing the scores for the dependent variable, namely the Average Student Satisfaction Score, and the independent variable, namely Faculty. Anova aims to compare more than two averages.

a. Test of Between Subject Effects

The Test of Between-Subjects Effects image above is the final result of the two-way ANOVA t-test that we need. The following is an explanation:

The basis for Decision Making in the Two Way Anova Test :

1. If the frequency count $<\mathrm{F}$ table or the value of sig $>0.1$, then $\mathrm{H} 0$ is accepted

2. If $\mathrm{F}$ count $>\mathrm{F}$ table or sig value $<0.1$, then $\mathrm{H} 0$ is rejected, so $\mathrm{H} 1$ is accepted

Decision:

From the table above, it can be seen that the calculated $F$ value is 1.256 or the significant

Table 1. Test of Between-Subjects Effects

Tests of Between-Subjects Effects

Dependent Variable: Average_Student_Satisfaction_Score

\begin{tabular}{lccccc}
\hline Source & Type III Sum of Squares & Df & Mean Square & F & Sig. \\
\hline Corrected Model & $21.855 \mathrm{a}$ & 7 & 3.122 & 9.374 & .000 \\
\hline Intercept & 23296.195 & 1 & 23296.195 & 69944.870 & .000 \\
\hline After_Before_COVID-19 & .272 & 1 & .272 & .815 & .367 \\
\hline Faculty & 20.328 & 3 & 6.776 & 20.344 & .000 \\
\hline After_Before_COVID-19* Faculty & 1.255 & 3 & .418 & 1.256 & .289 \\
\hline Error & 111.244 & 334 & .333 & & \\
\hline Total & 24676.110 & 342 & & & \\
\hline Corrected Total & 133.098 & 341 & &
\end{tabular}


value obtained from the table above is 0.289 . So it can be concluded: there is an \ interaction between the online class implementation model against the faculty groups.

b. Graph of Post Hoc Test Analysis Results of All Faculties

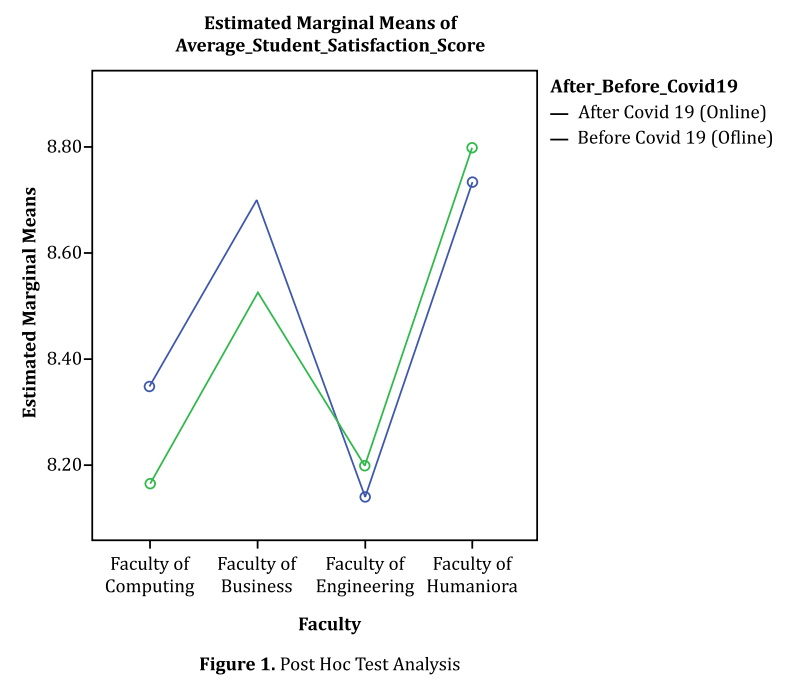

From the graph above it can be seen that for the Faculty of Computing, lectures after covid-19 (online class) are more effective than lectures before covid-19 (offline class) because courses that should be offline class use laboratory tools, when online. The class can be replaced by using new software that can be installed on a computer or laptop. The Faculty of Business lectures after covid-19 (online class) is more effective than before covid-19 (offline class). The Faculty of Engineering lectures before covid-19 (offline class) were more effective than after covid-19 (online class) and the Faculty of Humaniora lectures before covid-19 (offline class) were more effective than after covid-19 (online class).

After seeing the results of the calculation using the two way ANOVA from graph 4.2, it can be concluded that the lectures conducted before covid19 (offline class) and after covid 19 (online class) experienced an increase and decrease in performance, from 4 (four) faculties there were 2 (two) seen. Faculties that have experienced an increase after running online lectures, namely the Faculty of Computing and Faculty of Business, then 2 (two) Faculties have decreased when carrying out online lectures, namely the Faculty of Engineering and the Faculty of Humaniora, to find out why the authors conducted online interviews using Google meet with 12 (twelve) lecturers, namely from the four faculties each 3 (three) lecturers who were interviewed, for confidentiality, respondents were given the initials R1, R2, R3, R4, R5, R6, R7, R8, R9, R10, R11, and $\mathrm{R} 12$, here are the results of interviews and discussion results:

\section{What makes the Faculty of Computing and the Faculty of Business Increase in Performance When Running Online Classes}

The results of the interview show that in general learning that is carried out online is currently one of the necessities and needs for the world of education apart from the covid-19 outbreak, online learning or what is also known as electronic learning, e-learning, online Learning, internetenabled learning, virtual learning or web-based learning have previously been applied in several Indonesian and foreign universities, so indirectly these are factors of the times that must be followed so as not to be technologically illiterate. In particular, with the implementation of online lectures, Lecturers are encouraged to be more creative in providing material, namely by making learning videos in the form of tutorials uploaded on Youtube, maximizing the use of Google Classroom, Whatsaap Group, and video conferencing applications such as Google Meeting, Zoom, Skype, Hangout and Webex. As in the image below:

The key to all of this is a stable connection in the sense that if there are students who experience problems with bad connections, the lecturer opens a discussion session after learning hours are over or whenever students can contact the lecturer via WhatsApp so that communication is well maintained, where the lecturer must still pay attention to the development of their students. namely by ensuring the right to education continues even with technology intermediaries. For example, lectures that are delivered practically at the Faculty of Computing can be replaced with 


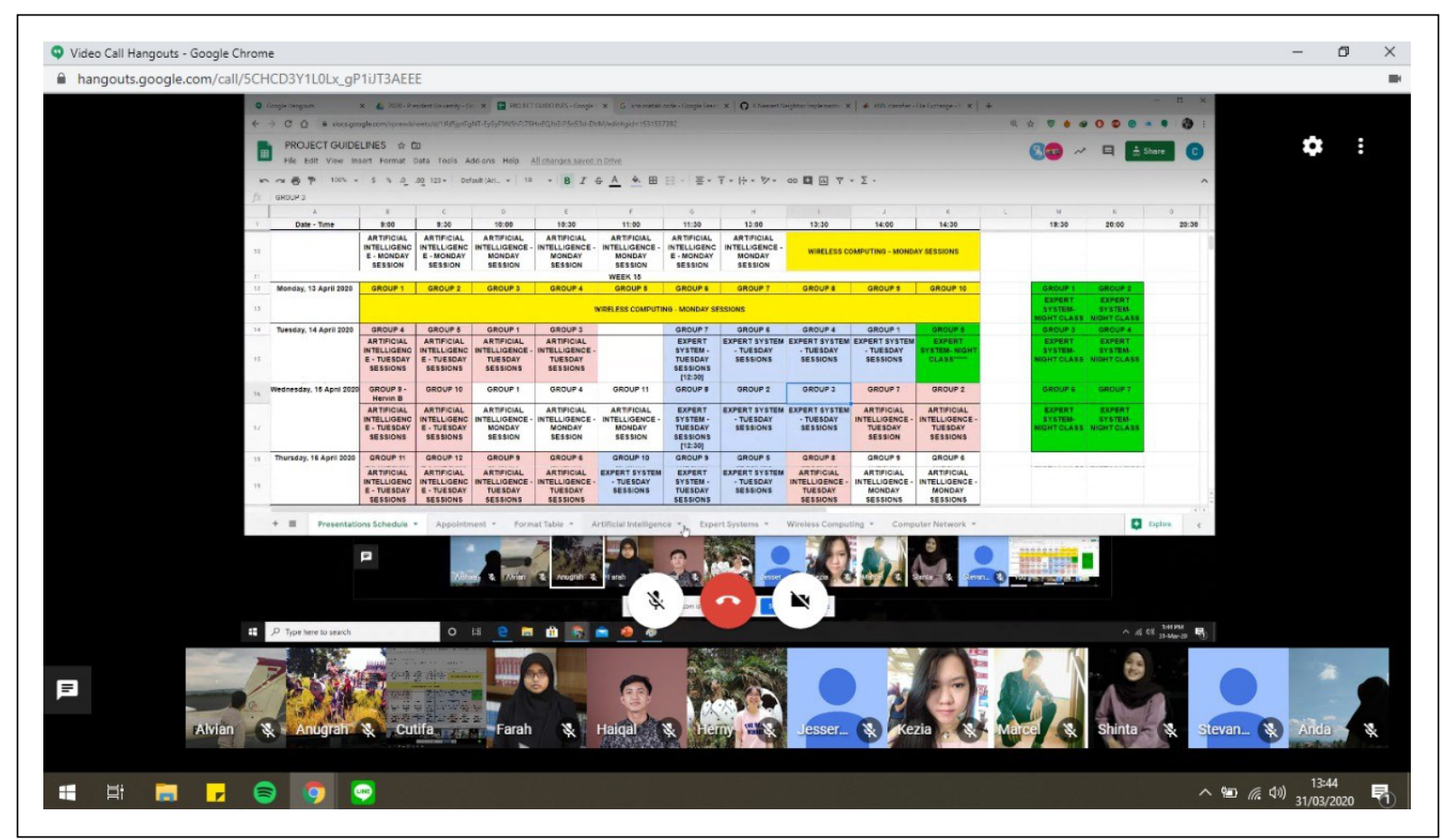

Source: Faculty of Computing Student, 2020

Figure 2. Lectures using Google Hangout

new software to support online lectures, and their use is not limited by time and space.

"The courses that should be offline in-class use laboratory tools, but when online classes are replaced by using software such as sqlzoo, luchidchart, GNS3 and other software to support these courses so that students become interested and enjoy attending lectures, it is different from when they have to be in the live lab, students are limited by time because the gentian lab is with the next student class schedule "-R1 and R2. One of the Lecturers

Online lectures are learning that can overcome problems in the teaching and learning process, for example with online classes students are more active in searching for reading literature sourced from the internet and at the same time providing solutions to students who experience problems in communication. During the online class, there will be no students who are embarrassed or nervous in conveying ideas or ideas. On the other hand, students are satisfied because of the flexibility in the implementation of lectures. Students are not pressured by time because they can set their schedule and place where they want to attend lectures. Lecturers also feel the same way, when running online classes they feel more enjoyable because they can do homework, hobbies, and if there are questions from students regarding material that has not been mastered, they can directly search the internet and can immediately answer them without having to burden a task (homework) for the next meeting. Through online learning, lecturers give lectures through virtual classes that can be accessed anywhere and anytime. This allows students to freely choose which courses to follow and which assignments to do first.

"Students prefer online classes because they can run lectures casually at home, are more relaxed in facing exams because there are no lecturers who supervise and if there is a material that is not understood, the lecturer allows asking via WhatsApp whenever there is no time limit" -R4. One of the Lecturers

Lectures delivered by both the Faculty of Computing and the Faculty of Business have their level of excitement, different difficulties, 
and of course have their challenges, it goes back to the person of lecturers and students how to respond to distance learning. Both lectures that are delivered materially and practically in online classes are essentially the same as providing new knowledge and experiences from both the lecturers and the students' sides.

\section{Things that caused the Faculty of Engineering} and the Faculty of Humaniora to experience a decrease in performance when running online classes

The results of the interview reinforce the explanation that the role of lecturers and students in this online lecture, which is quite long, is of course very important. Of course, unified collaboration must be maintained so that online lectures can continue to run effectively. Lecturers who are not accustomed to conducting online lectures generally only upload material in the form of pdf, word, or PowerPoint without sufficient explanation. This makes students who should need to be guided to understand the material unable to understand it optimally. As a result, the scores obtained by students eventually decreased when compared to the scores obtained when they studied directly in class. Not to mention the understanding of lecturers who replace assignments as material explanations, so that lecturers tend to give excessive assignments because they are considered students have to do these assignments as a substitute for study time at home, in other words, not online lectures, but online assignments. Of course, this also makes it very difficult for students because if all courses are taken, the lecturer applies the same system, then students will certainly get excessive assignments that will drain energy and mind.

"It could be that during an online class like this there are some lecturers who give too many assignments to students but there is not enough consultation so that students are stressed by piling up tasks". - R11. One of the Lecturers

For students majoring in social, online lectures are not a scary problem. Online classes seem to be as simple as moving a face-to-face presentation to Google Meet or replacing them with assignments via Google Classroom. Even though there are courses that are supposed to be done face-to-face because they have to understand body language, facial expressions, eye gaze, and speech intonation, they are not as complicated as compared to students majoring in science and engineering, where they have to carry out lectures that should be done. in practice both the laboratory and the field and now it has to be done online, it is very difficult and even impossible to do.

"When there are online classes, there are several courses that should be practiced directly in the lab but cannot be done. Even if there is a practicum, it can only be done in a visual way, which is demonstrated through videos or by looking for illustrations or animations that can describe the implementation of the practicum. For example in the Environmental Engineering study program, especially in the Micro-Biology course, you have to perform proper growth media and isolation of bacteria, it is rather difficult to find learning media because you have to go directly to the field and cannot be done during online classes. "- R8. One of the Lecturers

Besides that, one of the biggest challenges in distance learning systems is internet access. Because the lecture system has changed to online, the unfortunate fate of students who do not have Wi-Fi is that they have to spend more money to buy a quota or data package, even though there is a quota allowance from the campus but it is all considered insufficient because of all courses and assignments delivered online using a video conferencing platform, certainly, take up a lot of quota or data packages.

"Some students have expressed their complaints against lecturers, if they do not like online classes, the reason is that learning offline classes have difficulty understanding the material, especially online classes, not to mention the various obstacles such as the internet that does not support, broken 
quotas and various other technical obstacles" -R7. One of the Lecturers

Therefore, so that the material can be conveyed properly to all students, lecturers provide time and opportunity to open discussions and answer student questions outside of class hours via the WhatsApp application or discussion via WhatsApp groups so that all students can understand the material.

"Make sure the material reaches the students and if there are students who don't understand, the lecturer tries to incorrectly answer the student's questions at any time, outside class hours via the WhatsApp group so that all students who don't ask will understand" - R6. One of the Lecturers

Lectures delivered both materially and practically at the Faculty of Engineering and Faculty of Humaniora will be difficult to carry out, when lecturers and students have not found the right rhythm and teaching platform. So that things like that make students bored and dissatisfied when receiving online learning.

\section{Online Class Strategies To Be More Effective}

The results of the interview explained that online lectures are indeed not easy to do especially if the courses must be delivered in practice, however, some strategies can be done so that online classes continue to run well and fun, because basically, this is a big challenge, considering this. This is the first experience for lecturers, as well as students, it is very difficult to receive material online, especially if the course is supposed to be done in practice, as is the case in the Faculty of Computing, for Computer Network courses when offline class, usually the material is delivered using tools- tools in the laboratory, but during the online class the lab tools can be replaced by:

1. Using software such as Sqlzoo and luchidchart, plus new software that can be learned such as Gns3, Cisco, and Switch so that students can practice directly and explore the software.

2. Lecturers can share interesting applications to support online classes such as the
Mentimeter application for interactive presentations, the poll application for quizzes, and the Kahoot application, a game-based learning platform.

It is different with students in the Faculty of Engineering, the practicum is more difficult to do because it cannot be replaced by any software such as the Arduino course, the lecturer can only give a demo via video, then for courses that do have to go directly to the field it is very impossible to do but from There the lecturer provides strategies for students so that lectures can be passed properly, namely by:

1. Doing Asynchronously, namely, the Lecturer has prepared in advance the material that will be studied by students by recording and uploading it on E-Campus.

2. Calling the name of the student and holding a question and answer regarding the material that has been delivered with the aim that the lecturer knows whether the student understands the material presented or not.

For social students, lectures in practice may be rarely conducted because for the Faculty of Business, most of the lectures are delivered material, even if there are courses that must be explained by calculating formulas such as the Tax Accounting course, it can be assisted with a Drawing Pad tool, so that they can still explain. like on the whiteboard. In addition, lecturers at the Faculty of Business also provide strategies for students to enjoy online lectures, such as:

1. Distribute lecture material long before the lecture schedule starts, the goal is that students can study the material in advance.

2. Always try to engage to attract student participation, then the lecturer tries to identify students personally so that students feel cared for.

Unlike students in the Faculty of Humaniora, even though they are included in the social family, some courses must be delivered visually, because, in these courses, students are taught to understand body language. Then some courses must be carried out directly into the field such 
as in the Law study program, namely the Moot Court and Arbitration subject, which is a course that aims to provide experience for students to play a role and carry out procedures in court proceedings including the stages of reading a lawsuit, how to interact in the trial, where the position of the panel of judges, the position of the plaintiff and defendant, the defendant and his defense. All of these cannot be applied during online classes, even though this course is the subject most liked by students because they can see firsthand how the trial process is and of course an interesting experience for students. To get rid of boredom when running online classes, lecturers at the Faculty of Humaniora provide strategies, namely:

1. Do not give students an accumulated assignment.

2. Lecturers open discussions outside class hours through the WhatsApp application so that students can ask questions anytime and anywhere.

\section{CONCLUSION AND RECOMMENDATION}

Based on the results of the research conducted by the author, it can be concluded that there is a significant difference in satisfaction between lectures before Covid-19 (offline class) and after Covid-19 (online class) between faculties. During the offline class, students feel satisfied because they can get knowledge directly without any technical problems, whether it is material or practical learning. The face-to-face teaching and learning process has values that can be taken by students, such as the process of social, cultural, ethical, and moral maturation which can only be obtained by social interaction in an educational area. It is different when students do lectures remotely or online classes, many moments are lost, namely, the learning atmosphere is not as warm as being in class directly, no chemistry can be built, when online classes the lecturer cannot distinguish which students understand and which students who do not understand, then for courses that must be implemented in practice it is very difficult to do. Although from the other side, online lectures also provide special satisfaction for both lecturers and students, namely in terms of time efficiency, then lectures can be carried out casually at home and students are more relaxed in facing exams because no lecturer is supervising them.

There are differences in the characteristics of each faculty, for students majoring in social studies such as the Faculty of Business and the Faculty of Humaniora, online classes are not a serious problem, because lectures can be done only with the presentation of material, even though there are courses that do have to explain the formulas. formulas and solutions and some courses should be done face-to-face because they have to understand body language, facial expressions, eye gaze, and speech intonation, but they are not too complicated when compared to students majoring in engineering and science, such as the Faculty of Engineering, some lectures should be done in practice or practicum in the laboratory that cannot be done, although it can be tricked by making videos or by looking for illustrations and animations that can describe the implementation of the practicum, it still cannot replace it completely, especially if the course must be practiced. straight into the field, it just can't be done. It is different with the Faculty of Computing because basically, the knowledge that is learned about technology is that students do not have too much trouble carrying out online lectures, because instead, they can learn new lab replacement software such as sqlzoo, luchichart, Gns3, Cisco, Switch and other software that are not yet. Of course, you can get it when you are in offline lectures because it is limited by space and time.

Online classes will run more effectively if both lecturers and students live it with a sense of responsibility, namely that lecturers provide material correctly and can be received well by students, and students also carry out their obligations, namely taking classes and doing all the assignments given by the lecturer appropriately time. The point is that both parties must be able to collaborate and have a better understanding of the conditions that have occurred, and as much as possible give their best 
Yeni Fajrin, Adhi Setyo Santoso / The Effectiveness of the Implementation of Online Lectures on Student Satisfaction in Higher Education Institutions (Case Study of the President University) / 138 - 148

performance. Make the best use of technology, make a list of tasks that you want to do in a planned manner, try to always maximize communication between lecturers and students, never feel afraid of lecturers, and don't make students afraid of lecturers. The characteristics in each faculty are different, this is a challenge for lecturers to explore their abilities and provide new knowledge, and of course, it can be well accepted by students.

\section{REFEREN CES}

Adijaya, N., \& Santosa, L. P. (2018). Persepsi Mahasiswa Dalam Pembelajaran Online. http://ejournal.bsi.ac.id/ejurnal/index.php/wanastra, 10(2), 105-110.

Andini, N. F. (2020). Dampak Pembelajaran Daring Bagi Mahasiswa Masa Pandemi Covid-19. Universitas Negeri Makassar, 1-8.

Argaheni, N. B. (2020). Sistematik Review: Dampak Perkuliahan Daring Saat Pandemi Covid-19 Terhadap Mahasiswa Indonesia. PLACENTUM Jurnal Ilmiah Kesehatan dan Aplikasinya, 8(2), 99-108.

Ayu, D. P., \& Amelia, R. (2020). Pembelajaran Bahasa Indonesia Berbasis E-Learning Di Era Digital. Prosiding SAMASTA, 56-61.

Aziz, A., Ekasari, S. R., Supriyadi, A., Nurcholis, A., Latifah, N. A., Arif, M., et al. (2020). Kuliah Daring Dinamika Pembelajaran Ketika Wabah Corona. (A. A. Moebin, Ed.) Tulungagung: IAIN TULUNGAGUNG PRESS.

Basori. (2014). Efektifitas Komunikasi Pembelajaran Online Dengan Menggunakan Media E-Learning Pada Perkuliahan Body Otomotif. JIPTEK, 7(2), 39-45.

Fathurrahman, A., Sumardi, Yusuf, A. E., \& Harijanto, S. (2019). Peningkatan Evektivitas Pembelajaran Melalui Peningkatan Kompetisi Pedagogik Dan Teamwork. Jurnal Manajemen Pendidikan, 7(2), 843-850.

Firman, \& Rahman, S. R. (2020). Pembelajaran Online di Tengah Pandemi Covid-19. Indonesian Journal of Educational Science (IJES), 02(02), 1-9.

Garrison, D. R., \& Cleveland-Innes, M. (2005). in Online Learning: Interaction Is Not Enough. American Journal of Distance Education. https://doi.org/10.1207/s15389286ajde1903

Giesbers, B., Rienties, B., Tempelaar, D., \& Gijselaers, W. (2020). A dynamic analysis of the interplay between asynchronous and synchronous communication in online learning: The impact of motivation. Journal of Computer Assisted Learning, 30-50.

Gilbert, B. (2015). Online Learning Revealing the Benefits and Challenges. https://fisherpub.sjfc.edu/, 1-31. Hariyanti, E., \& Purwanti, E. (2017). Pengukuran E- Learning Readiness Untuk Mendukung Keberhasilan Pengembangan E-Learning (Studi Kasus : Fst-Universitas Airlangga),(August).

Hendrastomo, G. (2018). Dilema dan Tantangan Pembelajaran E-Learning. Dimuat dalam Majalah Ilmiah Pembelajaran, 4(1), 1-13.

Hidayati, N. (2010). Sistem E-Learning Untuk Meningkatkan Proses Belajar Mengajar: Studi Kasus Pada SMA Negeri 10 Bandar Lampung. Jurnal TELEMATIKA MKOM, 1(2), 153-170.

Kedraka, K., \& Kaltsidis, C. (2020). Effects Of The Covid-19 Pandemic On University Pedagogy: Students' Experiences And Considerations. European Journal of Education Studies, 7(8), 17-30.

Khan, S. (2012). The one world schoolhouse: Education reimagined. Twelve.

Kolpashnikova, K., \& Bartolic, S. (2019). The Digital Divide in Quantitative Methods. The Effects Of Computer-Assisted Instruction And Students' Attitudes on Knowledge Acquisition. Journal of Computer Assisted Learning, 35(2), 208-217. 
Yeni Fajrin, Adhi Setyo Santoso / The Effectiveness of the Implementation of Online Lectures on Student Satisfaction in Higher Education Institutions (Case Study of the President University) / 138 - 148

Kusnayat, A., Muiz, M. H., Sumarni, N., Mansyur, A. S., \& Zaqiah, Q. Y. (2020). Pengaruh Teknologi Pembelajaran Kuliah Online Di Era Covid-19 dan Dampaknya Terhadap Mental Mahasiswa. EduTeach : Jurnal Edukasi dan Teknologi Pembelajaran, 1(2), 153-165.

Mulawarman, W. G. (2020). Persoalan Dosen dan Mahasiswa Masa Pandemik Covid 19: Dari Gagap Teknologi Hingga Mengeluh Boros Paket Data. Prosiding Seminar Nasional Hardiknas (pp. 37-46). Samarinda: Universitas Mulawarman.

Nguyen, T. (2015). The Effectiveness of Online Learning: Beyond No Significant Difference and Future Horizons. MERLOT Journal of Online Learning and Teaching, 11(2), 309-319.

Pakpahan, R., \& Fitriani, Y. (2020). Analisa Pemanfaatan Teknologi Informasi Dalam Pembelajaran Jarak Jauh Di Tengah Pandemi Virus Corona Covid-19. JISAMAR (Journal of Information System, Applied, Management, Accounting and Researh), 4(2), 30-36.

Permejo, Gilbert dan Cuaton. (2020). Philippine Higher Education Institutions in the time of COVID-19 Pandemic. Journal of Multidimensional Education for April/Mei 2020 Special Issue.

Pujiasih, E. (2020). Membangun Generasi Emas Dengan Variasi Pembelajaran Online di Masa Pandemi Covid-19. Jurnal Karya Ilmiah Guru , 5(1), 42-48.

Purwandani, I. (2018). Pengukuran Tingkat Kepuasan Mahasiswa Pengguna Elearning dengan Menggunakan End User Computing (EUC) Satisfaction Studi Kasus: Akademi Bina Sarana Informatika. Seminar Nasional Inovasi dan Tren (SNIT), 112-117.

Purwandani, I. (2020). Analisa Tingkat Kepuasan Pengguna Elearning Menggunakan EUCS dan Model Delone and McLean. IJSE - Indonesian Journal on Software Engineering, 10(10), 99-106.

Purwanto, Agus et. all. (2020). Impact of Work From Home (WFH) on Indonesian Teachers Performance During the Covid-19 Pandemic: An Exploratory Study. International Journal of Advanced and Technology. Vol 29. No 5.

Purwanto, A., Pramono, R., Asbari, M., Santoso, P. B., Wijayanti, L. M., Hyun, C. C., et al. (2020). Studi Eksploratif Dampak Pandemi COVID-19 Terhadap Proses Pembelajaran Online di Sekolah Dasar. Journal of Education, Psychology and Conseling, 2(1), 1-13.

Rokhani, Cicilia Tri Suci. (2020). Pengaruh Work From Home (WFH) Terhadap Kinerja Guru SD Negeri Dengkek 01 Pati Selama Masa Pandemi Covid-19. EduPsyCouns: Journal of Education, Psychology and Counseling, 2(1), 424-437.

Sadikin, A., \& Hamidah, A. (2020). Pembelajaran Daring di Tengah Wabah Covid-19. BIODIK: Jurnal Ilmiah Pendidikan Biologi, 06(02), 214 - 224.

Setyorini, I. (2020). Pandemi Covid-19 dan Online Learning: Apakah Berpengaruh Terhadap Proses Pembelajaran Pada Kurikulum 13? Journal of Industrial Engineering \& Management Research (JIEMAR), 01(01), 95-102.

Silalahi, T. F., \& Hutauruk, A. F. (2020). The Application of Cooperative Learning Model during Online Learning in the Pandemic Period. Budapest International Research and Critics Institute-Journal (BIRCI-Journal), 3(3), 1683-1691.

Swan, K. (2002). Building Learning Communities in Online Courses: the importance of interaction. Education, Communication \& Information. https://doi.org/10.1080/1463631022000005016

Szpunar, K. K., Moulton, S. T., \& Schacter, D. L. (2013). Mind-wandering and education: from the classroom to online learning. Frontiers in psychology, 4, 495.

Tusevljak, M., Majcen, L., Mervar, L., Stepankina, T., \& Cater, B. (2016). E-Learning In Higher Education: Focus Groups And Survey Among Students In Central Europe. i-manager's Journal of Educational Technology, 13(2), 11-20.

Yuniastari S, N. A., \& Wiyati, R. K. (2015). Pengukuran Tingkat Efektivitas Dan Efisiensi Sistem Eresearch STIKOM Bali. Konferensi Nasional Sistem \& Informatika, 562-568. 